Int. J. Dev. Biol. 52: 141-146 (2008)

doi: $10.1387 / \mathrm{ijdb} .082605 \mathrm{hb}$

\title{
History and status of embryology and developmental biology at Polish Medical Faculties and Schools
}

\author{
HIERONIM BARTEL* \\ Department of Histology and Embryology, Medical University of Lodz, Poland
}

\begin{abstract}
In Poland, medical embryology (both scientific research and teaching of the subject) has traditionally involved Chairs of Histology and Embryology rather than Obstetrics and Gynecology. Before World War II, the most buoyant centers for embryological research among the five universities at the time (in Warsaw, Krakow, Poznan, Lvov and Vilnius), were the Chairs of Embryology and Histology at Medical Faculties of the Jagiellonian University in Krakow and the University of Vilnius. After World War II, eleven Medical Academies (Universities of Medicine) came into being (Warsaw, Krakow, Poznan, Lodz, Gdansk, Bialystok, Bydgoszcz, Szczecin, Wroclaw, Katowice and Lublin). They conduct scientific research on normal development of the human embryo as well as teratology studies. In the XX century, eminent medicine-related embryologist included professors Emil Godlewski Jr., Stanislaw Hiller and Stefan Baginski.
\end{abstract}

KEY WORDS: history, embryology, medicine, Poland

Before 1939, Poland had five universities: in Warszawa (Warsaw), Krakow (Cracow), Poznan, Lwow (presently Lviv in Ukraine) and Wilno (presently Vilnius in Lithuania). In all of them the Chairs of Histology and Embryology belonged to the Faculties of Medicine.

With World War II coming to an end in 1945, Medical Faculties operating before the war in the Universities of Warsaw, Cracow and Poznan, were reopened alongside with Medical Faculties set up in newly established universities. In 1947, Medical Sciences were separated from the universities to become independent Schools of Medicine (Medical Academies), and as such they have survived until today with some minor organizational restructuring. Currently there are in Poland eleven Medical Schools in the following cities: Warsaw, Cracow (re-united with the Jagiellonian University as the Colegium Medicum), Poznan, Lodz, Gdansk, Bialystok, Bydgoszcz, Szczecin, Wroclaw, Katowice, and Lublin. All these Medical Schools (with the exception of Gdansk with independent Laboratory of Embryology and Krakow with the Department of Human Developmental Biology) have chairs and/ or departments of Histology and Embryology that teach and carry out research in embryology, histology and cell biology.

\section{Krakow}

The history of embryological research at the Medical Faculty of the Jagiellonian University before and shortly after the end of
World War II, with special emphasis on the activity of Professor Emil Godlewski Jr., is described in Sliwa, 2008 (pp. 97-100 in this issue). The Department of Human Developmental Biology at Colegium Medicum of the Jagiellonian University is currently headed by docent Sliwa who works on chemotaxis in mammalian fertilisation (Sliwa, 2003, 2004).

\section{Warszawa}

Before World War II Professor Mieczyslaw Konopacki (killed by a bomb in September 1939) headed Histology and Embryology Chair at Warsaw University (see Bielanska-Osuchowska, 2008, pp. 147-150 in this issue). In autumn of 1945 the Department of Histology and Embryology re-opened under the direction of professor Juliusz Zweibam, who worked in this department before the war, and luckily survived detention in the Warsaw ghetto and Warsaw upraising in 1944. In those first difficult post-war years Zweibam was helped by Bronislawa Konopacka, a wife (and also a prominent scientist) of the former head of the Department, Professor Konopacki. It was not until 1950 that the Department of Histology and Embryology moved back to the rebuilt Anatomicum building, where it had been housed before the war. Zweibaum and Konopacka began to shape a research profile of the new team by introducing the techniques of tissue culture and histochemistry. They were also very active in academic life on a national scale they reactivated Polish Anatomical Society and its official journal,

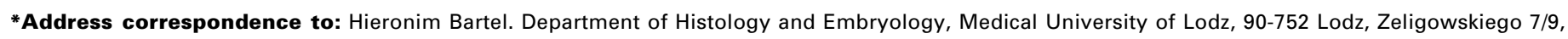
Poland. Tel/fax: +48-42-632-4087. e-mail: bartel@achilles.wam.lodz.pl

Published online: 14 February 2008 
Folia Morphologica. In 1955 Kazimierz Ostrowski was nominated a docent in the Department and in 1956 he became a head of the Chair and the Department of Histology and Embryology. He had remained at this post until retirement in 1992. Under his leadership the Department grew and became very active in research introducing new and modern techniques and trends into experimental studies in histology and developmental biology. The Department, the largest among similar Departments in the remaining Polish Medical Schools, has also conferred the highest number of Doctor of Medicine degrees and Professor titles. The scientific interests of the Department have concentrated, among other subjects, on in vitro induction of osteogenesis by various tissues, Maloney sarcoma virus and factors stimulating secretion of cytokines (Wlodarski, 1969; Wlodarski et al., 1979), and on various aspects of structure and organisation of skeletal tissues (Ostrowski et al., 1991, 1993,). The group headed by Professor Moskalewski studied histogenesis of cartilage in vivo and in vitro and showed that individual chondrocytes are able to reconstitute the cartilage when transplanted into a recipient (Moskalewski, 1965; Moskalewski and Kawiak, 1965; Moskalewski et al., 1975,1983). Another line of research related to preimplantation mouse embryos has been carried out by PhDs/MDs: Wojciech Sawicki, Wanda Stodolnik-Baranska, Marek Kujawa, Jan Abramczuk and three PhD biologists: Ewa Mystkowska, Aldona Komar and Anna Niemierko (Baranska et al., 1975; Mystkowska etal., 2001; Sawicki and Mystkowska, 1999; Sawicki etal., 2006). (Earlier research of Mystkowska, Komar and Niemierko in the Department of Embryology at Warsaw University and in the Laboratory of Experimental Embryology is covered by Tarkowski et al., 2008, pp. 121-134 in this issue). The research on early mammalian development was stimulated by the visits to Wistar Institute in Philadephia and collaboration with Hilary Koprowski and Davor Solter. This research resulted in several publications, among them an important, and cited for decades by many researchers, study of DNA synthesis in mouse one-cell embryos obtained after fertilization or artificial activation (Abramczuk and Sawicki, 1975). Ostrowski and his collaborators have written or translated several embryology and histology textbooks, many of which had several editions.

\section{Poznan}

Department of Histology and Embryology at the Medical Academy of Poznan was established in 1920. Between 1922 and 1959 (with the exception of the period of German occupation) it was headed successively by Professor Tadeusz Kurkiewicz (18851962), Kazimierz Mietkiewski (1906-1973), Andrzej Lukaszyk, and since 2006 by Maciej Zabel. One of the most important studies published by this group are the histochemical studies of Mietkiewski and his co-workers on the development of human fetal male gonads (Mietkiewski et al., 1966), and on sperm cytogenesis in the rat (Mietkiewski and Lukaszyk, 1967). These studies were cited in the fundamental monography of the male gonad development edited by Dalcq (1973). Mietkiewski with collaborators also studied pathology of the development of male reproductive system: cryptorchidism, testicular ectopy, and disorders of testicular descent (Mietkiewski et al., 1964), and the role of hydrolase and oxidoreductase in the development of chicken kidney (Mietkiewski and Lukaszyk, 1966, 1967).

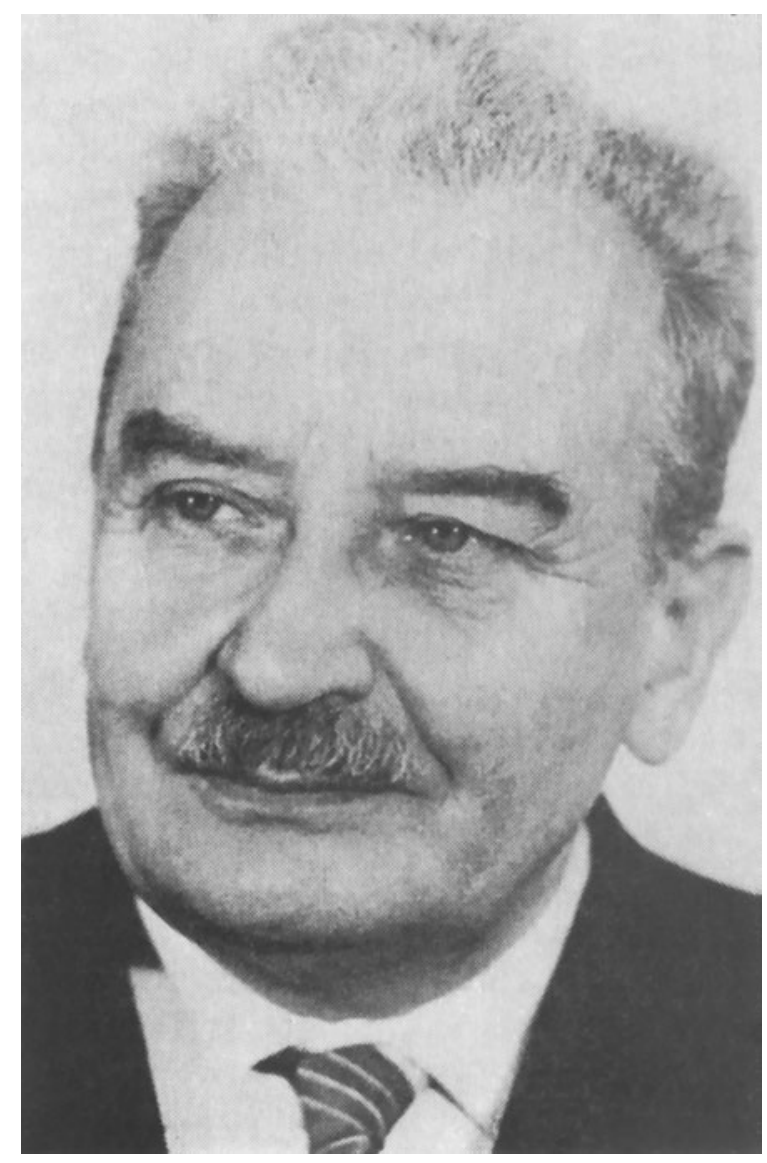

Fig.1. Professor Stanislaw Hiller (1891-1965), Editor-in-Chief of Folia Morphologica during 1957-1964.

Professor Ludwik Malendowicz (former student of Mietkiewski) working together with scientists from the Department of Human Anatomy, applied stereology to the study of human adrenal glands and thyroid gland in early foetal life (Bocian-Sobkowska et al., 1996, 1997).

Professor Maciej Zabel (the youngest of Professor Mietkiewski's students), and his team performed a number of immunocytochemical studies on the development of pancreatic endocrine cells in man and pig (Zabel et al., 1994; (Bocian-Sobkowska et al., 1996, 1997ab).

Professor Jerzy Warchol, a student and a long-time co-worker of Mietkiewski (currently the chief of the Department of Cell Biology at University School of Medical Sciences in Poznan), for many years had carried out ultrastructural studies of normal and pathological sperm in humans.

The Department of Anatomy of the University School of Medical Sciences in Poznan headed successively by Professor Witold Wozniak (1975-95) and Professor Malgorzata Bruska (since 1995 until present) has conducted extensive studies on the development of human organs at various stages of foetal development. An Embryological Collection established in this Department contains 205 serially sectioned human embryos and 300 foetuses acquired from legal abortions in OB-GYN Hospitals post mortem injected via umbilical vein with $4 \%$ formaldehyde.

In 1967-1968 Dr. Witold Wozniak was appointed a visiting 
professor of Anatomy in Saint Louis University School of Medicine, St. Louis, Missouri, where he worked under the guidance of Dr. Ronan O'Rahilly, professor of anatomy and embryology, and chairman of the Department of Anatomy. Wozniak discovered that the hypoglossal nerve in foetuses contain nerve cells, which resemble cells of the inferior ganglion of the vagus nerve (Wozniak and Young, 1968). Between 1974 and 1982 human developmental studies in the Departmant of Anatomy were performed in collaboration with Carnegie Institution of Embryology as a part of "Normal development of nervous system in humans" research program. As a result of this collaboration a sequence of events in differentiation and maturation of nerve cells in the spinal ganglia and in the inferior ganglion of the vagus nerve were described at the ultrastructural level (Olszewska et al., 1979; Bruska and Wozniak, 1980).

OB-GYN Clinic at the Medical Academy in Poznan, under Professor Tadeusz Pisarski, carry out studies in the field of placentology, prenatal diagnostics and other areas of human embryology. Pisarski wrote a comprehensive textbook of Obstetrics and Gynecology containing thorough description of human prenatal development and placenta (Pisarski, 2002)

\section{Gdansk}

In 1945 Professor Stanislaw Hiller (1891-1965) was appointed a Head of Histology and Embryology Department in the Medical Academy in Gdansk (Fig. 1). Before World War II, between 1929 and 1939, Hiller was a head of Histology and Embryology Department at the Stefan Batory University in Wilno. During the Nazi occupation of Wilno Hiller taught in his apartment the clandestine classes in histology and embryology for Polish medical students.

Hiller was a student of eminent scientists of the Jagiellonian University: Napoleon Cybulski (Physiology), Kazimierz Kostanecki (Anatomy) and Emil Godlewski Jr (Embryology). In the 1920's, greatly impressed by the achievements of his mentor Emil Godlewski in the field of developmental biology, Hiller started embryological research, studying among other subjects the effect of ethyl alcohol on the development of the frog, and later focusing on regeneration in the axolotl. On several occasions he returned to the latter problem together with his co-workers Associate Professors Stanislaw Baginski and Jan Kruszynski, and enriched these studies by introducing the histochemical techniques. As a Rockefeller Foundation Scholar, he visited USA in 1927, where he worked under Professor R. Chambers on the effect of various drugs on amoeba. These studies published together with Chambers and Pollack are referred to in numerous textbooks of pharmacology (e.g. Clark, A.J. "General Pharmacology"). Hiller also studied the development of mesonephros in amphibians (Rana fusca, Triton taeniatus) and the effect of parabiosis on the structure of mesonephros. Between 1948 and 1950 he published several papers on the early development of the human embryo, based on the studies that he had completed before the war. Hiller is recognized as one of the pioneers of histochemistry in Poland; he organised in his Department a Laboratory of Histochemistry, which conducted research on organogenesis.

Professor Hiller played an active role in reviving research and scientific institutions in post-war Poland. Between 1957 and 1964 he was the Editor-in-Chief of the journal 'Folia Morphologica' and it was at that time that the journal began to publish articles in

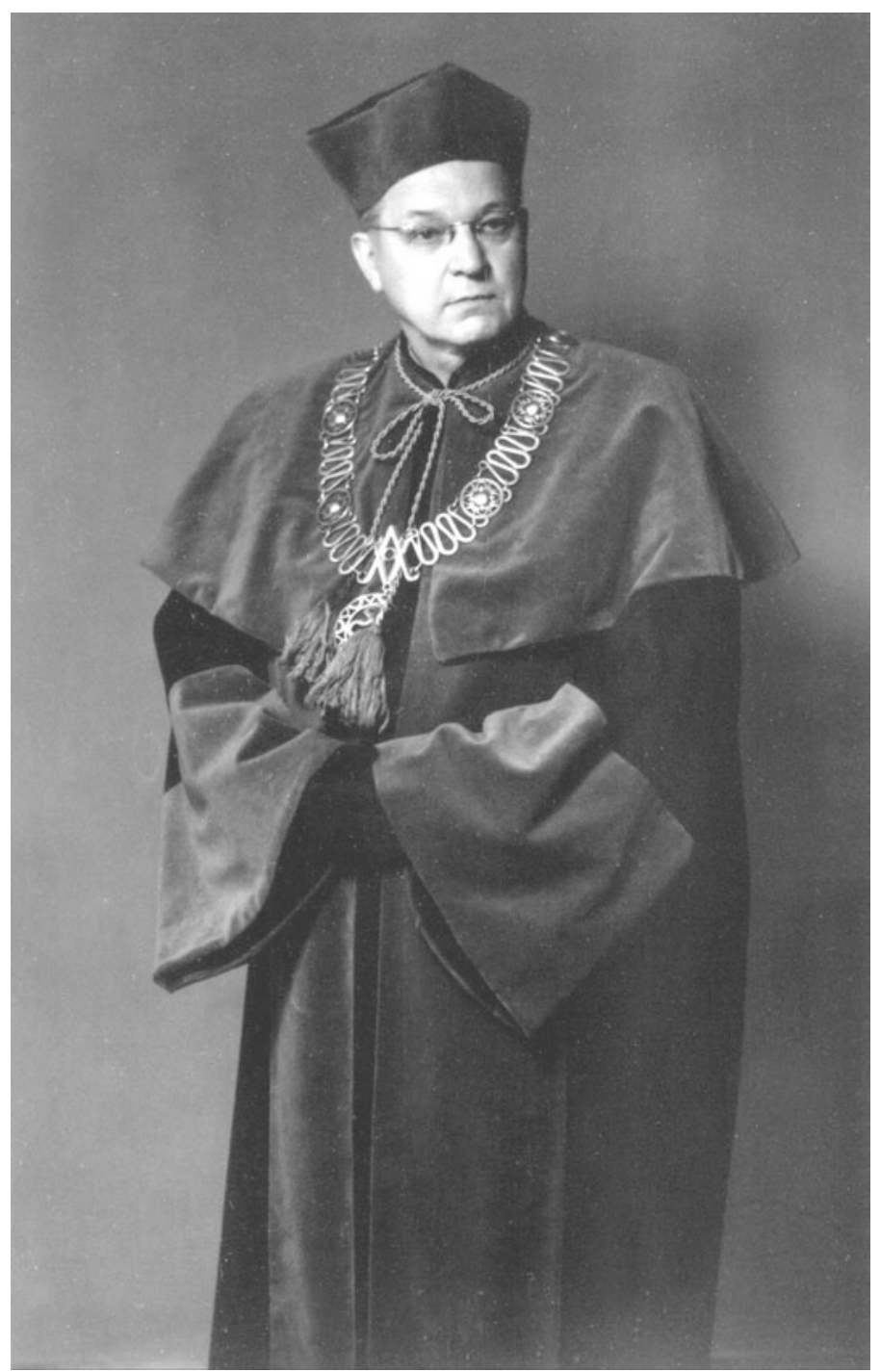

Fig. 2. Professor Stefan Baginski (1892-1969), legendary dean of the Medical Faculty of the Medical Academy of Lodz during 1948-1958.

English. Shortly after World War II, at the request of the widow of the late Emil Godlewski, Jr., Hiller prepared the third updated edition of Godlewski's textbook of Embryology which first edition was published in 1924. He also wrote several chapters on the development, physiology and histology of human tissues and organs for the seven-volume textbook "Anatomy of Man", edited by Bochenek and Reicher and published in 1952.

At the end of his tenure Hiller was replaced by Professor Stanislaw Zawistowski (1919-1990). In subsequent years Embryology evolved from the Chair to an independent Laboratory of Embryology headed in succession by Professor Zofia Zegarska and Professor Krystyna Kozlowska.

\section{Lodz}

Professor Stefan Baginski (1892-1969) (Fig. 2), who before World War II had obtained degree of Doctor of Medicine and veniam legendi from the Histology and Embryology Department 
at University of Wilno, laid the foundations for the department of Histology and Embryology at the Medical Academy of Lodz and headed it from 1945 to 1962.

He focused on congenital abnormalities in humans. Together with his daughter, Irena Borsuk (Baginski and Borsuk, 1967), he studied a 20-day old human embryo retrieved from an ovarian ectopic pregnancy during surgical intervention. The embryo was classified as stage 9 and listed as one of the earliest human embryos by Ranon O'Rahilly (1973). The studies of this embryo led to an important discovery of the origin of angioblasts and confirmed the view that angioblast of the pleuropericardial area develops from the embryo's own mesenchymal cells.

Baginski also published several papers on sex chromatin and genetic sex determination. Towards the end of his professional career, and ahead of his times, he touched on the problem of stem cells publishing several papers on the socalled cambial cells. He formulated a concept of mesodermal origin of cambial cells and complementing cells that degenerate after birth (Baginski, 1966).

Baginski was one of the founders of the Military Medical Academy and in 1958, he became the first chairman of the Department of Histology and Embryology. Between 1964 and 1991 the Department headed by Professor Leszek Cieciura, carried out studies on prenatal development of humans and experimental animals, as well as the research in teratology.

At the beginning of his scientific career, Cieciura - using a wide range of then state-of-the-art histochemical methods focused mainly on the development of the human placenta, placenta fibrinoid, and hydrolytic enzymes (phosphatases) in the connective tissue layer surrounding the seminiferous rat tubule in the rat testis exposed to X-rays and microwaves. Later, he had introduced morphometric methods to electron microscopy studies in cell biology, and pioneered in Poland the freeze-fracture technique. This technique was used to study metabolic changes in mitochondria (Cieciura et al., 1986a). Many of his studies had been performed in collaboration with foreign research groups (Cieciura et al., 1986b).

Since 1991, the Department has been run by Cieciura's student- Professor Hieronim Bartel. In 2002, two medical schools in Lodz - military and civil - merged giving rise to the Medical University of Lodz. Originally, Bartel studied ultrastructure of ovum implantation in the mouse (Bartel, 1971; Bartel and Cieciura, 1972), and on the basis of EM images he reconstructed a complete early embryo of the mouse (Bartel, 1972). Working together with OB-GYN specialists, he performed a number of studies of the ultrastructure of human placenta, focusing on Hofbauer cells, capillaries of the villi in the placental barrier under normal developmental conditions, and placenta disorders (gestosis). In addition, Bartel has studied the development of human and mouse thymus at the ultrastructural level and written an Embryology textbook for medical students and medical doctors; its fourth edition was published in 2004.

In the 1970ties, the Department launched experimental teratological studies. These studies showed that the large doses of caffeine administered to pregnant mice cause extensive hematoma in the mouse embryonic limb buds, preventing normal formation of the limbs (Snigorska and Bartel, 1970). Apart from continuing studies of caffeine effects on reproduc- tion and foetal development, the Department is also involved in foetal alcohol syndrome and foetal tobacco syndrome research.

\section{Szczecin}

Histology and Embryology Department at the Pomorska Medical Academy in Szczecin (headed between1984 and 2002 by Professor Lidia Wenda-Rozewicka, and since 2002 by Professor Barbara Wiszniewska) has recently launched studies aimed at identification of morphologic and functional defects in human sperm and their relationship to molecular changes in DNA. They have shown that defects of mitochondrial sheath of human sperm occur in combination with molecular damage to sperm DNA. A number of methods were applied to supplement routine sperm diagnostic procedures, such as cytochemical, cytofluorometric, fluorescent, immunohistochemistry and ultrastructural methods (Piasecka, M. and Kawiak, J., 2003; Piasecka, et al., 2006). Other researchers from the same department focus on mouse embryogenesis. Their studies of preimplantation mouse embryos have shown that certain growth factors promote development of blastocyst in the mouse (Kurzawa et al., 2001), and provide protection against an oxidative stress (Kurzawa et al., 2004; Glabowski et al., 2005).

\section{Wroclaw}

OB-GYN Clinic of the Medical Academy in Wroclaw under the management of Professor Janusz Woyton (1974 - 2002) has studied various aspects of the composition of human amniotic fluid: concentration of proteins, enzymes, electrolytes, and creatinine. These observations had been summarised in a monograph of the physiopathology of the amniotic fluid (Woyton, 1981).

\section{Bialystok}

On November 12, 1987 the Gynaecology Clinic of Medical Academy headed by Professor Marian Szamatowicz delivered the first IVF baby (a girl) in Poland. For many years the Clinic has specialized in infertility treatment that resulted in approximately 2,500 IVF births.

There are six assisted reproductive technology centres in Polish medical schools, and 18 commercial IVF clinics. It is difficult to estimate how many IVF births have taken place in Poland that does not have any laws regulating this method of infertility treatment.

\section{Lublin}

In 1982 Professor Zygmunt Urbanowicz (chief of the Department between 1979 and 1983) founded in the Department of Anatomy at Medical University of Lublin the Teratology Unit, which was set up to perform various developmental studies. In 2002 Professor Franciszek Burdan became a scientific supervisor of teratological team. Currently, the Lublin Teratology Unit is one of the most active experimental teratological centres in Poland.

The scientific activities of this centre focus on the reproductive toxicity of cyclooxygenase (COX) inhibitors and their interaction with caffeine. The single- and multigenerational studies showed 
the developmental toxicity of various non-selective and selective COX-2 inhibitors, and indicated that caffeine increases the prenatal toxicity of the over-the-counter COX inhibitors. A retrospective statistical analysis was performed on the basis of data collected in the laboratory in the years 1997-2004 during different teratological studies with COX-inhibitors - aspirin, DFU, DuP-697, ibuprofen, paracetamol, piroxicam, propyphenazone and tolmetin. They have shown that of the whole group of COX-inhibitors, especially the non-selective COX inhibitors significantly increase the incidence of the congenital ventricular septal defect and celosomy (gastroshisis, umbilical hernia). In addition, these studies showed, for the first time, the presence of dark chondrocytes in the rat fetal epiphyseal cartilage (Burdan et al., 2002, 2005, 2006a and b).

In collaboration with Professor Chahoud (Freie University of Berlin) the Lublin's group also established a novel digital radiological method for bone mineralization assessment (Burdan et al., 2002).

\section{References}

ABRAMCZUK, J., SAWICKI, W. (1975). Pronuclear synthesis of DNA in fertilized and parthenogenetically activated mouse eggs. Exp. Cell Res. 92: 361-371.

BAGINSKI, S. (1966). Précis de la théorie du "Cambium du tissu animal" Arch. histol. jap. 27: 77-80.

BAGINSKI, S. and BORSUK, I. (1967). Micromorphology of the human embryo from the third week of pregnancy. Folia Morphol. 26: 147-153.

BARANSKA, W., KONWINSKI, M. and KUJAWA, M. (1975). Fine structure of the zona pellucida of unfertilized egg cells and embryos. J. Exp. Zool. 192: 193-202.

BARTEL, H. (1971). Histochemical and electronmicroscopic investigations of the process of ovum implantation in mice. Folia Medica Lodziensia 14: 107-138.

BARTEL, H. (1972). Electron microscopic observations of the inner cell mass of mouse embryo. Acta anat. 83: 289-301.

BARTEL, H. and CIECIURA, L. (1972). Studies on the trophoblastic nidation of the mouse ovum. Z. mikrosk. anat. Forsch. Leipzig, 86: 369-382.

BIELANSKA-OSUCHOWSKA, Z. (2008). Bronislawa and Mieczyslaw Konopacki pioneers of the application of histochemistry to embryology in Poland. Int. J. Dev. Biol. 52: 147-150.

BOCIAN-SOBKOWSKA, J., MALENDOWICZ, L.K. and WOZNIAK, W. (1997). Comparative stereological study on zonation and cellular composition of adrenal gland of normal and anencephalic human fetuses. II. Cellular composition of the gland. Histol. Histopathol. 12:391-399.

BOCIAN-SOBKOWSKA, J., WOZNIAK, W., MALENDOWICZ, L.K., GINDA, W. (1996). Stereology of human fetal adrenal medulla. Histol. Histopathol. 11: 389393.

BOCIAN-SOBKOWSKA, J., ZABEL, M., WOZNIAK, W., SURDYK-ZASADA, J. (1997). Prenatal development of the human pancreatic islet immunocytochemical identification of insulin-, glucagon-, somatostatin- and pancreatic polypeptide- containing cells. Folia Histochem. Cytobiol. 35: 151-154.

BRUSKA, M. and WOZNIAK, W. (1980). Ultrastructural studies on differentiation of nerve cells in the human embryonic and fetal inferior ganglion of the vagus. Anat. Anz. 148: 30-41.

BURDAN, F., ROZYLO-KALINOWSKA, I., ROZYLO, T.K., CHAHOUD, I. (2002). A new, rapid radiological procedure for routine teratological use in bone ossification assessment: a supplement for staining methods. Teratology, 66: 315-325.

BURDAN, F., SZUMILO, J., DUDKA, J., KOROBOWICZ, A., KLEPACZ, R. (2006a). Congenital ventricular septal defects and prenatal exposure to cyclooxygenase inhibitors. Braz. J. Med. Biol. Res. 39: 925-934.

BURDAN, F., SZUMILO, J., KOROBOWICZ, A., KLEPACZ, R. (2006b). Celosomy is associated with prenatal exposure to cyclooxygenase inhibitors. Pharmacol. Res. 53: 287-292.

BURDAN, F., SZUMILO, J., MARZEC, B., KLEPACZ, R., DUDKA, J. (2005).
Skeletal developmental effects of selective and nonselective cyclooxygenase2 inhibitors administered through organogenesis and fetogenesis in Wistar CRL: (WI)WUBR rats. Toxicology, 216:204-223.

CIECIURA, L., RYDZYNSKI, K., PIETA, P. and KLIMEK, I. (1986). Freeze-fracture studies on mitochondrial membranes of spermatocytes. Cell Tissue Res. 244: 437-441.

CIECIURA, L., NILSSON, B.O., PIETRZKOWSKA, K. and WANDACHOWICZ, I. (1986). Morphometry of mitochondrial changes in mouse trophoblast cells at early implantation. J. Submicrosc. Cytol. 18: 133-136.

DALCQ, A.M. (1973). Cyto-morphologie normale du testicule et spermatogenese chez les Mammiferes, Palais des Academies, Bruxelles, 1-834.

GLABOWSKI, W., KURZAWA, R., WISZNIEWSKA, B., BACZKOWSKI, T., MARCHLEWICZ, M. and BRELIK, P. (2005). Growth factors effects on preimplantation development of mouse embryos exposed to tumor necrosis factor alpha. Reprod. Biol. 5:83-99.

KURZAWA, R., GLABOWSKI, W., WENDA-ROZEWICKA, L. (2001). Evaluation of mouse preimplantation embryos cultured in media enriched with insulin-like growth factors I and II, epidermal growth factor and tumor necrosis factor alpha. Folia Histochem. Cytobiol. 39: 245-251.

KURZAWA, R., GLABOWSKI W., BACZKOWSKI, T., WISZNIEWSKA, B. and MARCHLEWICZ, M. (2004). Growth factors protect in vitro cultured embryos from the consequences of oxidative stress. Zygote, 12: 231-240.

MIETKIEWSKI, K., KOPACZYK, F., WALCZAK, M. (1964). Contribution a l'etude de la criptorchidie et de l'ectopie du testicule human. Bull. Assoc. Anat. 49: 1202-1214

MIETKIEWSKI, K., CYMERYS, Z., WALCZAK, M. (1966). Histology and histochemistry of the human fetal testis. Arch. Anat. Microsc. Exp. 55(1): 23-35.

MIETKIEWSKI, K., LUKASZUK, A. (1966). The histochemistry of some dehydrogeneses in course of chick kidney histogenesis. Arch. Biol. 77(4): 677697.

MIETKIEWSKI, K., LUKASZYK, A. (1966). Determination of alpha-glycerolphosphate dehydrogenase activity during spermatogenesis in the testis of the rat. Histochemie, 7: 28-38.

MIETKIEWSKI, K., LUKASZYK, A. (1967a). Interrelation of the ultrastructure of mitochondria and endoplasmic reticulum to the histochemistry of some dehydrogenases in the course histogenesis of the kidneys in the chick. Folia Morphol. 26: 1-13.

MIETKIEWSKI, K., LUKASZYK, A. (1967b). Use of the alpha-glycerophosphate dehydrogenese reaction for the estimation of the functional differentiation of the rat germinal epithelium. Histochemie, 11: 216-222.

MOSKALEWSKI, S. (1965). Isolation and culture of the islets of Langerhans of the guinea pig. Gen. Comp. Endocrinol. 5: 342-353.

MOSKALEWSKI, S., BOONEKAMP, P.M. AND SCHERFT, J.P. (1983). Bone formation by isolated calvarial osteoblasts in syngeneic and allogeneic transplants: Light microscopic observations. Amer. J. Anat. 176: 249-263.

MOSKALEWSKI, S. AND KAWIAK, J. (1965). Cartilage formation after homotransplantation of isolated chondrocytes. Transplantation 3: 737-747.

MOSKALEWSKI, S., THYBERG, J., LOHMANDER, S. AND FRIBERG, U. (1975). Influence of colchicines and vinblastine on the Golgi complex and matrix deposition in chondrocyte aggregates. Exp. Cell Res. 95: 440-454.

MYSTKOWSKA, E.T., NIEMIERKO, A., KOMAR, A. and SAWICKI W (2001). Embryotoxicity of magainin-2-amide and its enhancement by cyclodextrin, albumin, hydrogen peroxide and acidification. Human Reprod 16: 1457-1463.

OLSZEWSKA, B., WOZNIAK, W., GARDNER, E. and O'RAHILLY, R. (1979). Types of neural cells in the spinal ganglia of human embryos and early fetuses. Z. mikrosk. anat. Forsch. 6: 1182-1199.

O'RAHILLY, R. (1973) Developmental stages in human embryos. Carnegie Institution of Washington, Publication 631.

OSTROWSKI, K., DZIEDZIC-GOCLOWSKA, A., STACHOWICZ, W. and MICHALIK, J. (1991).nRadiation-induced paramagnetic centers can be utilized in research of bone physiopathology as well as in dosimetry of absorbed dose of ionizing radiation. Clin. Orthopeadics and Related Res. 272: 21-29.

OSTROWSKI, K., DZIEDZIC-GOCLAWSKA, A., STACHOWICZ, W. and MICHALIK, J. (1993). Changes in cristallinity of bone mineral in development, healing and pathology estimated by electron spin resonanse (ESR) spectrometry. Calc. 
Tiss. Int/. 52 (Suppl.1): 52.

PIASECKA, M. and KAWIAK J. (2003). Sperm mitochondria of patients with normal sperm motility and with asthenozoospermy: morphological and functional study. Folia Histochem. Cytobiol. 41: 125-239.

PIASECKA, M., GACZARZEWICZ, D. and LESZCZYNSKA, M. (2006). Evaluation of sperm genomic integrity of normozoospermic men: a prospective study. Folia Histochem. Cytobiol. 44: 117-122.

SAWICKI, W. T., KUJAWA, M., JANKOWSKA-STEIFER, E., MYSTKOWSKA, E. T., HYC, A. and KOWALEWSKI, C. (2006). Temporal/spatial expression and efflux activity of $A B C$ transporter, P-glycoprotein /Abcb1 isoforms and Bcrp/ Abcg2 during early murine development. Gene Expression Patterns, 6: 738746.

SAWICKI, W. and MYSTKOWSKA, E.T. (1999). Contraceptive potential of peptide antibiotics. Lancet 353: 464-465.

SLIWA, L. (2003). Effect of transforming growth factors (TGF $\alpha$ and TGF $\beta$ ) on human sperm chemotactic migration in vitro. Arch. Androl. 49: 155-159.

SLIWA, L. (2004). Chemotaxis effect of platelet activating factor on mouse spermatozoa in vitro condition. Arch. Androl. 50: 31-35.

SLIWA, L. (2008). Emil Godlewski, Jr. (1875-1944) pioneer of embryology at the
Jagiellonian University of Krakow (Poland). Int. J. Dev. Biol. 52: 97-100.

SNIGORSKA, B. and BARTEL, H. (1970). Studies on the teratogenic influence of caffeine on white mouse fetuses. Folia Morphol. 29: 316-325.

TARKOWSKI, A.K., MALESZEWSKI, M., ROGULSKA, T., CIEMERYCH, M.A. and BORSUK, E. (2008). Mammalian and avian embryology at Warsaw University (Poland) from XIX century to the present. Int. J. Dev. Biol. 52: 121-134.

WLODARSKI, K. (1969). The inductive properties of epithelial established cell lines. Exp. Cell Res. 57: 446-448.

WLODARSKI, K., JAKOBISIAK, M. and LUCZAK, M. (1979). Orthotopic bone induction at sites of Moloney murine sarcoma virus inoculation in mice. Nature 281: 386-387.

WOYTON, J. (1981). Physiopathology of the amniotic fluid (in Polish: Fizjopatologia plynu owodniowego). PZWL, Warszawa.

WOZNIAK, W. and YOUNG, P.A. (1968). Nerve cells in the extracranial portion of the hypoglossal nerve in human fetuses. Anat. Rec. 162: 517-522.

ZABEL, M., SURDYK-ZASADA, J., LESISZ, I., JAGODA, E., WYSOCKA T., SEIDEL, J., GRZESZKOWIAK, J. (1994). Immunocytochemical studies on pancreatic endocrine cells at early stages of development of the pig. Folia Histochem. Cytobiol. 32: 181-185.

\section{Related, previously published Int. J. Dev. Biol. issues}

See our recent Special Issue Developmental Biology in Poland edited by Kloc, Maleszewski and Tarkowski at: http://www.ijdb.ehu.es/web/contents.php?vol=52\&issue=2-3

See our Special Issue Mammalian Reproduction \& Development in honor of Anne McLaren and edited by Brigid Hogan at: http://www.ijdb.ehu.es/web/contents.php?vol=45\&issue=3

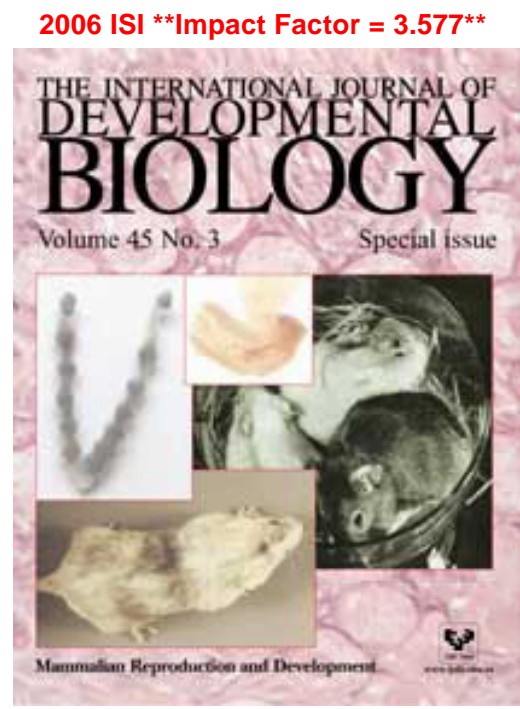

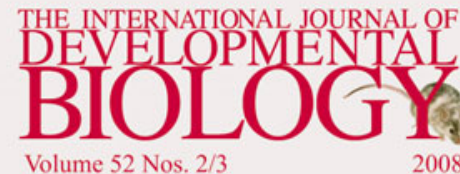

Volume 52 Nos. $2 / 3$

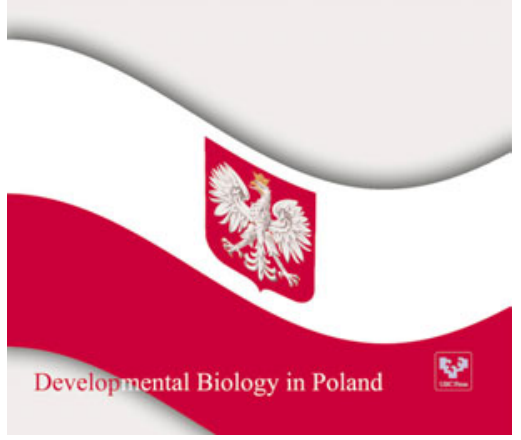

